would appear a sufficiently heavy task, for from west to east "are to be found Sherchokpas, Sherdukpen, Tembangias, Khoas, Akas, Mijis, Miri Akas, Daflas, Apa Tanangs and Miris, all differing in language, custom and dress. .. . The Western tribes are peaceful and well disposed to us. The Daflas and Apa Tanangs are, however, inclined to be truculent and it is impossible to tour in their country without an escort",

The conifers discussed in the paper are Pinus excelsa, $P$. longifolia (in extensive pure forests), Abies delavayi, in pure crops on the northern slopes of Piri, between $9,000 \mathrm{ft}$. and $10,727 \mathrm{ft}$.; its home is in Szechuan, China, this being a new record of its presence in Assam. Associated with it are species of Rhododendron, oak, etc.

Perhaps the most interesting of the investigations carried out are those recorded in connexion with Pinus excelsa. This conifer occurs in two places only - -the Tenga valley in the west and the Apa Tanang country to the east, two localities which are some 150 miles apart. In the Tenga valley the climate is dry, and the tree flourishes at between 5,000 ft. and $9,000 \mathrm{ft}$. Regeneration of the $P$. excelsa is very satisfactory if protection from fire is afforded.

The most interesting information with reference to this species comes from the Apa Tanang country. Here the rainfall is much higher, the elevation being $6,000-7,000 \mathrm{ft}$. The tree reaches a great size, $150 \mathrm{ft}$. in height with a girth of $14 \mathrm{ft}$. The wood of $P$. excelsa is used largely by the Apa Tanangs as fuel and for building material.

The most striking feature of this valley is the fact that the pine grows pure on the inner slopes only of the bowl, and pine trees are not found beyond the lip. On all sides the evergreen forest is apparently encroaching upon the pine, and dead pine trees can be seen emerging high above the evergreen forest on the inner side of the lip. A meticulous search in the pure pine forest failed to reveal a single seedling, showing that the pine seed cannot germinate and develop in the present conditions. It seems as if the pine is a remnant of a very large area of pure pine which is slowly dying out. In any event, it is clear that the Quercus-Michelia-Acer hylium is advancing upon it and will eventually prevail. This view is confirmed by certain of the Apa Tanang's elders, who told Dr. Bor that the area under pine has decreased even within their time, and that their forefathers had come to the same conclusion as that outlined above, and had as a consequence with considerable foresight ordered the tree to be raised in plantations. Seed is broadcast on hoed ground and the area protected from fire.

In the Zhob country of the Baluchistan frontier, the Sheranis attach equal value to the Pinus gerardiana both for its seed and timber, and endeavour to protect these forests from fire. But Dr. Bor's account of an aboriginal tribe successfully raising plantations by the cheap measures recorded must be unique.

\title{
Broadcasting in India
}

$\mathrm{T}$ $\mathrm{HE}$ growth of radio broadcasting during recent years has been so marked that in most of the larger European countries, in the United States of America, in Australia and in Canada, the number of registered listeners exceeds five per cent of the population. Actually, the number of licensed listeners in Great Britain and Northern Ireland at the end of 1934 amounted to about 15 per cent of the population. In India, however, with its population of more than 350 millions, the number of registered listeners is less than 12,000 , or about 0.003 per cent. This fact, with many others illustrating the very elementary stage attained by radio broadcasting in India, is given in a paper by $\mathrm{Mr}$. $\mathrm{K}$. Sreenivasan entitled "Development of Nationwide Radio Broadcasting in India", published in Electrotechnics for April 1935.

After reviewing the ideals and objects of a national broadcasting service in any country, Mr. Sreenivasan discusses the status of broadcasting in various parts of the world, illustrating the main facts with a useful table of statistical data. He then passes on to the consideration of a broadcasting scheme suitable for India to replace the three existing transmitting stations. The suggested scheme involves the installation of about five national transmitting stations and sixty regional stations, with an additional five short-wave transmitters for international longdistance broadcasting. The proposed distribution of these stations is illustrated by a map, and the scheme is considered to be adequate to serve all interests and requirements, having due regard to the various languages involved. In the matter of power allocation, each of the national transmitters would have $250 \mathrm{kw}$. in the antenna, the regional stations would vary between $25 \mathrm{kw}$. and $75 \mathrm{kw}$., while the short-wave stations would be of $50 \mathrm{kw}$. rating. This gives a total power of nearly $5,000 \mathrm{kw}$., or about one watt per square kilometre for India, as compared with the existing figure of about $2 \cdot 3$ watts per square kilometre for Great Britain.

With regard to the distribution of receivers, $\mathrm{Mr}$. Sreenivasan considers that, owing to the low standard of living prevalent in India, particularly in rural districts, there is no satisfactory alternative to community ownership of receivers and community listening. Even so, it is estimated that some $3 \frac{1}{2}$ million receivers will be required as an immediate objective.

The paper then proceeds to a consideration of the outline of an organisation of an autonomous public utility type for the provision, maintenance and operation of this national broadcasting service. It is suggested that a central broadcasting council should work under a Minister of Communications, and in co-operation with a number of provincial broadcasting commissions. Further sections are devoted to proposals for financing the project and to the policy underlying the programmes to be provided. In conclusion, the author modestly expresses the hope that his paper will help to create a correct perspective of the vast problem involved in the matter of broadeasting in India, and will provoke reasoned discussion on this national question. 